\title{
Virological and immunological aspects of AIDS pathogenesis
}

\author{
BRIAN CONWAY MD FRCPC, FRANCISCO J DIAZ-MITOMA MD PhD FRCPC
}

\begin{abstract}
B Conway, FJ Diaz-Mrtoma. Virological and immunological aspects of AIDS pathogenesis. Can J Infect Dis 1994;5(Suppl E);13E-18E. The most common and serious problem associated with long term antiretroviral therapy is waning efficacy over time. To date, a number of studies has suggested an association between drug resistance and clinical deterioration. However, a precise causal relationship has yet to be demonstrated. In a large American clinical trial, resistance to zidovudine (ZDV) was predictive of subsequent disease progression if this therapy was continued. Surprisingly, this was also predictive of deterioration if therapy was changed to didanosine (ddI). This suggests that other factors (perhaps virological and immunological) which may be present in addition to resistance, were as important (if not more so) in predicting clinical outcomes. It is likely that viral load, resistance, viral phenotype and alterations in immune function interact in this regard. Proper studies may allow us to determine a 'threshold' for a composite virological and immunological parameter beyond which disease progression will occur. As more antiretroviral agents become available, we will be in a position to intervene to 'improve' laboratory markers and monitor them prospectively, potentially to maintain clinical latency for an indefinite period of time. In the authors' laboratories, a quantitative polymerase chain reaction assay for the evaluation of circulating proviral load has been developed. In an initial study of 70 patients, proviral load $/ 10^{6} \mathrm{CD} 4$ cells was clearly associated with the severity of immune disease, with up to $9.6 \%$ of cells being infected in subjects with CD4 cell counts below $200 / \mu \mathrm{L}$. However, large variability in proviral load among individuals with comparable or dissimilar $\mathrm{CD} 4$ cell counts precludes the use of this measurement as an individual marker of the severity of immune disease. More recent work evaluated the combined use of proviral load (expressed as a dichotomous variable based on values above or below one copy $/ 10^{3} \mathrm{CD} 4$ cells) and resistance in a prospective fashion. In five patients with high proviral loads and isolates resistant to their current therapy, a mean decrease of $72 \mathrm{CD} 4$ cells/ $\mu \mathrm{L}$ was observed over 12 months of observation. In contrast, in six patients with low proviral loads and sensitive isolates, there was a mean increase of $43 \mathrm{CD} 4 \mathrm{cells} / \mu \mathrm{L}$. It appears that virological markers are associated with immune disease progression in this small cohort of patients. The association appears most marked when the two virological parameters are considered together rather than individually. The association is not always a tight one, and this may relate to a number of unmeasured factors, including viral phenotype, plasma viremia, and the immune response to HIV infection. Additional work incorporating these parameters into analysis is currently underway in the authors' centre. (Pour résumé, voir page 14E)
\end{abstract}

Key Words: AIDS, Antiviral resistance, Cytokines, Proviral load

Department of Microbiology \& Immunology, University of Ottawa, Division of Infectious Diseases, Ottawa General Hospital; Department of Molecular Virology, Children's Hospital of Eastern Ontario Research Institute, Ottawa, Ontario

Correspondence and reprints: Dr Brian Conway, Ottawa General Hospital, 501 Smyth Road, Room G12, Ottawa, Ontario K1H 8L6. Telephone (613) 737-8442, Fax (613) 737-8141 


\section{Aspects virologiques et immunologiques de la pathogenèse du sida}

RÉSUMÉ : Le problème le plus fréquent et le plus grave associé au traitement antirétroviral prolongé est l'atténuation progressive de son efficacité. Jusqu'à présent, un certain nombre d'études ont suggéré un lien entre la résistance aux médicaments et la détérioration de l'état clinique. Ce rapport de cause à effet reste toutefois à démontrer. Un essai clinique d'envergure mené aux États-Unis sur la résistance à la zidovudine $(\mathrm{ZVD})$ a servi à prévoir l'évolution de la maladie si le traitement était interrompu. Étonnamment, cela a aussi permis de prévoir la détérioration de l'état si le traitement était remplacé par la didanosine (ddI). Cela donne à penser qu'en plus du phénomène de résistance, d'autres facteurs (peut-être virologiques et immunologiques) jouent un rôle tout aussi important (voire plus important) dans la prédiction du pronostic. Il est probable que la charge virale, la résistance, le phénotype du virus et les modifications de la fonction immunitaire interagissent à ce chapitre. De bonnes études pourraient nous permettre de déterminer le seuil d'un paramètre virologique et immunologique composite au-delà duquel la maladie progressera. À mesure que d'autres agents antirétroviraux font leur apparition, nous serons en mesure d'intervenir pour "améliorer" les épreuves de laboratoire qui servent de marqueurs et les surveiller de façon prospective afin de possiblement maintenir la latence clinique durant une période de temps indéfini. Dans les laboratoires des auteurs, un dosage des réactions de polymérisations en chaîne pour l'évaluation de la charge provirale circulante a été mis au point. Dans une étude prêliminaire sur 70 patients, la charge provirale $/ 10^{6}$ cellules CD4 a clairement été associée à la gravité de la maladie immunitaire, jusqu'à 9,6\% des cellules étant infectées chez les sujets dont la numération des CD4 est infêrieure à 200/ $\mu \mathrm{L}$. Toutefois, la grande variabilité interindividuelle des charges provirales, que les numérations des CD4 soient comparables ou dissemblables, empêche l'emploi de cette mesure comme marqueur individuel de la gravité de la maladie immunitaire. Des travaux plus récents ont évalué le recours combiné à la charge provirale (exprimée sous forme de variable dichotomique sur la base de valeurs supérieures ou inférieures à une copie $/ 10^{3}$ cellules $\mathrm{CD} 4$ ) et à la résistance, de façon prospective. Chez cinq patients, dont les charges provirales étaient élevées et les isolats résistants au traitement courant, une diminution moyenne de 72 cellules CD $4 / \mu \mathrm{L}$ a été observée au cours des 12 mois d'observation. Par contre, chez six patients dont la charge provirale était basse et les isolats sensibles, on a noté une augmentation moyenne de $43 \mathrm{cD} 4 / \mu \mathrm{L}$. Il semble que les marqueurs virologiques soient associés à la progression de la maladie immunitaire dans cette petite cohorte de patients. L'association semble la plus forte lorsque deux paramètres virologiques sont pris ensemble plutôt qu'individuellement, mais elle n'est pas toujours bien étroite et cela peut être lié à un certain nombre de facteurs non mesurés, y compris le phénotype viral, la virémie plasmatique et la rêponse immunitaire à l'infection au viH. D'autres travaux qui intégreraient ces paramètres à l'analyse sont actuellement en cours au laboratoire de lauteur.

$\mathrm{T}$ HE PATHOGENESIS OF HIV INFECTION LEADING TO FULLblown' AIDS follows a very precise sequence of events (1). Following exposure to the virus, there is, in many cases, a period of symptomatic primary infection, which is self-limited. Within a number of weeks, it gives way to a period of clinical latency, which usually lasts many years. The process of viral emergence from latency is poorly understood, but it heralds the development of profound immunodeficiency, with frequent life threatening opportunistic infections.

A number of specific parameters has been associated with this observed disease progression (2). These include immunological (increased beta-2 microglobulin and neopterin, and decreased HIV-specific humoral and cellular responses), and virological (increased plasma and cell associated viral load) measures. Conversely, strongly preserved nonspecific and specific immune function and low circulating and tissue-bound viral load have been associated with clinical stability and long term survival $(2,3)$.

Characteristics associated with increased virulence in the host include an enhanced cellular host range, rapid kinetics of replication and increased syncytium inducing capacity (4). It is clear that an increased understanding of the homeostasis between virological and immunological determinants of disease progres- sion will increase our insight with respect to the events surrounding the emergence from viral latency and assist us in the design of optimal health maintenance strategies for HIV-infected patients.

\section{VIRAL LOAD MEASUREMENT}

Guantitative HIV cultures of plasma and circulating mononuclear cells were first described in 1989 (5). A clear association was noted between viral load and immune disease. It was suggested that symptoms would develop when a 'threshold' value of $10^{3}$ viruses/ $\mathrm{mL}$ of blood was exceeded. In long term prospective follow-up of four patients, this appeared to remain correct (6). These individuals were clinically stable as long as their circulating viral load remained unchanged. A rise in load preceded the development of opportunistic infections, although a precise causal relationship could not be established.

With the advent of the polymerase chain reaction (PCR), a more rapid and powerful tool became available for the measurement of viral load (7). Using a quantitative PCR assay developed in our laboratory, we measured circulating proviral load in the mononuclear cells of 70 study patients (8). Results were expressed as a function of the severity of immune disease, according to CD4 cell count categories (Table 1). 
A wide range of proviral loads was observed in each category. Thus we, as others, have shown that proviral load in itself cannot be used for individual disease staging. However, in the groups, a clear association was observed between increasing load and progressive immune disease, with up to $9.6 \% \mathrm{CD} 4$ cells infected in some patients. In addition, when expressing proviral load as a dichotomous variable, we found that in individuals with $\mathrm{CD} 4$ cell counts above $500 / \mu \mathrm{L}$ only one of 10 had high circulating proviral loads (more than $10^{3}$ copies $/ 10^{6} \mathrm{CD} 4$ cells), compared with 23 of 31 with cell counts below $200 / \mu \mathrm{L}(\mathrm{P}<0.001)$. Thus, a threshold-type phenomenon may be present with respect to the clinical significance of this parameter.

\section{ANTIRETROVIRAL RESISTANCE}

First developed as an anticancer drug in 1964 (9), zidovudine (ZDV) was found to have activity against HIV in 1985 (10). Several clinical trials have established the efficacy and toxicity of ZDV in a variety of HIV-associated conditions. The most common and serious problem associated with long term ZDV therapy is waning efficacy over time. The isolation of HIV with reduced susceptibility to ZDV was initially reported in 1989 (11). Generally, there appears to be a relationship between in vitro resistance and the duration of antiviral therapy. In addition, it appears that resistance occurs more rapidly in patients with advanced HIV infection (12). To date, a number of studies has suggested an association between ZDV resistance and clinical or immunological deterioration; however, a precise causal relationship has yet to be demonstrated. In a recent large American study, the baseline prevalence and clinical significance of $\mathrm{ZDV}$ resistance was examined in a group of patients on long term ZDV therapy who were randomized to continued ZDV or a change to didanosine (ddI) (13). As expected, baseline ZDV resistance was predictive of clinical deterioration if this therapy was continued. Surprisingly, this was also predictive of deterioration if therapy was changed to ddI. This suggests that other factors (perhaps virological and immunological) which were also present in individuals with resistant isolates, were as important (if not more so) than resistance itself in predicting impending deterioration. It should be stated that, in this study, the mean CD4 cell count in participating patients was below 50 cells $/ \mu \mathrm{L}$. In addition, a Canadian study of patients with very mild disease (CD4 more than 500 cells $/ \mu \mathrm{L}$ ) showed a clear association between ZDV resistance and disease progression while on ZDV (14). It is more likely that, in such individuals, the negative effect of ZDV resistance could have been observed in isolation, in the absence of other confounding variables.

In our centre, we have prospectively followed 31 patients to study the correlation between in vitro susceptibility and clinical outcome, as measured by changes in CD4 cell counts (15). Seventeen of 19 indi-
TABLE 1

Circulating proviral load in HIV-infected individuals, expressed as a function of the level of CD4 cell depletion

\begin{tabular}{llcc}
\hline $\begin{array}{r}\text { CD4 cell count } \\
\text { (cells } / \mu \mathrm{L})\end{array}$ & \multicolumn{2}{c}{$\begin{array}{c}\text { Proviral copies } / 10^{6} \text { CD4 cells } \\
\text { Mean }\end{array}$} \\
\hline$>500 \quad(n=10)$ & 721 & Range \\
$200-500 \quad(n=31)$ & 2507 & 3 to 5335 \\
$<200 \quad(n=29)$ & 10,453 & 9 to 17,922 \\
\hline
\end{tabular}

viduals with resistant isolates showed immune disease progression, compared with two of 12 with sensitive isolates. It is interesting to note that the two individuals with resistant isolates and stable disease had CD4 cell counts above 300 cells $/ \mu \mathrm{L}$, and likely lower circulating viral loads. In contrast, the two who progressed with susceptible isolates had CD4 cell counts below 50 cells $/ \mu \mathrm{L}$, and likely higher viral loads. This underscores the probable relationship between at least two virological parameters in the prediction of disease progression.

\section{ADDITIONAL VIROLOGICAL PARAMETERS}

Recent data suggest that the HIV biological phenotype (defined by the capacity to induce syncytia during co-cultivation with donor lymphocytes) may predict the response to therapy. In one study, one of 20 individuals who spent 559 months harbouring a nonsyncytiuminducing (NSI) phenotype progressed to AIDS, whereas progression was observed in eight of 12 who spent 223 months harbouring a syncytium-inducing si phenotype (16).

Viral phenotype analysis can be easily incorporated into a model examining multiple virological measures. As such, a group of 32 patients on ZDV therapy was followed prospectively for a mean duration of 34 months (17). Over time, patients' viral isolates could be classified as sensitive or resistant (S/R) to ZDV, and NSI/SI. Thus, four groups could be generated according to these two parameters (Table 2). Patients in the R/SI group had the most significant decrease in CD4 cell count over the period of observation and the highest circulating proviral load. Conversely, patients with the most favourable virological profile (S/NSI, low proviral load) had the most favorable CD4 cell count profile.

In our centre, we identified a cohort of 22 HIV-infected individuals, all of whom had received long term ZDV therapy and had experienced at least a 30\% decline in CD4 cell count since initiating this therapy (18). Patients either remained on ZDV therapy or were changed to ddI, according to their physicians' discretion. In prospective follow-up, monthly CD4 cell counts were obtained. In addition, every three months, circulating proviral load was measured by quantitative PCR. Susceptibility to current antiretroviral therapy was also measured at the same point in time.

At entry, there were eight individuals with zDV-susceptible isolates and 14 with resistant strains. There 
TABLE 2

A prospective analysis of changes in CD4 cells/ $\mu \mathrm{L}$ and absolute proviral load (HIV copies/ $10^{6} \mathrm{CD} 4$ cells) in 32 patients on ZDV therapy, classified according to viral phenotype (NSI/SI) and ZDV resistance status (S/R) according to genotypic analysis

\begin{tabular}{lcccr}
\hline & S/NSI & S/SI & R/NSI & R/SI \\
\hline Number of patients & 10 & 6 & 10 & 6 \\
Change in CD4 cells/ $\mu \mathrm{L}$ & +27 & -66 & -160 & -257 \\
HIV $/ 10^{6} \mathrm{CD} 4$ cells & 575 & 1380 & 2512 & 21.480 \\
\hline
\end{tabular}

NSI Nonsycytium-inducing; R Resistant: S Sensitive; SI Syncytium-inducing: ZDV Zidovudine

were no observable differences in CD4 cell counts (283 and 289 cells $/ \mu \mathrm{L}$, respectively). We proceeded to examine changes in CD4 cell counts over 12 months as a function of baseline virological measures (Table 3). When proviral load was expressed as a dichotomous variable, individuals with higher loads showed a mean decrease in CD4 cell count $(-38$ cells $/ \mu \mathrm{L})$, compared with the others $(+17$ cells $/ \mu \mathrm{L})$. Similarly, there appeared to be a relationship between drug susceptibility and deterioration in immune function (Table 3). However, a more striking relationship between virological parameters and CD4 cell counts was observed when proviral load and resistance were considered together. Over one year of observation, six patients with low proviral loads and susceptible viral strains showed a mean increase of $43 \mathrm{CD} 4$ cells $/ \mu \mathrm{L}$. In contrast, five patients with high load and resistant strains had a mean decrease of 72 CD 4 cells $/ \mu \mathrm{L}$.

\section{IMMUNOLOGICAL PARAMETERS}

As stated above, the development of effective antiviral drugs is hampered by the rapid emergence of drug resistance and of viral phenotypes that are more pathogenic. In this context, an understanding of the relationship between virological measurements and immune dysfunction may be of importance in the design of alternative therapeutic modalities to avoid HIV disease progression.

Cellular and humoral immune responses to HIVassociated antigens develop one to three months after infection $(19,20)$. The relationship between the development of neutralizing antibodies to envelope glycoproteins and HIV disease progression remains controversial $(21,22)$. However, cytotoxic T lymphocytes specific for HIV antigens (23) may confer resistance to HIV disease progression (24) and their activity decreases with clinical deterioration (25). The loss of $\mathrm{T}$ helper function precedes and predicts the rate of decline in CD4 cell numbers $(26,27)$. T helper cells sequentially lose the ability to respond to recall antigens, alloantigens and finally to mitogens (28). Alloantigen and mitogen responses improve on antiretroviral therapy, but not the responses to recall antigens. Because these latter responses are dependent on memory cells, and there is a
TABLE 3

Changes in CD4 cell count over 12 months of observation, expressed as a function of proviral load and drug susceptibility, considered individually or as a composite virological parameter (cells $/ \mu \mathrm{L}$ )

\begin{tabular}{lcr}
\hline Proviral load (copies/ $10^{6}$ CD4 cells) & \\
$\geq 1000$ (high) & 9 & -38 \\
$<1000$ (low) & 13 & +17 \\
Drug susceptibility & & +18 \\
$\begin{array}{l}\text { Susceptible } \\
\text { Resistant }\end{array}$ & 10 & -25 \\
Composite parameter & 12 & \\
High/resistant & & -72 \\
High/susceptible & 5 & +5 \\
Low/resistant & 4 & +8 \\
Low/susceptible & 7 & +43 \\
\hline
\end{tabular}

selective depletion of memory cells in HIV infection, improved $\mathrm{T}$ helper function may be more easily achieved for responses that are less dependent on these cells (29). There is little effect on responses involving antigen presentation by monocytes. The observed improvement in $\mathrm{T}$ helper function seen in some patients may correlate with clinical stability in the absence of any changes in CD4 cell counts (30), which suggests the need to include $\mathrm{T}$ helper function tests as markers of disease progression.

Monocytes synthesize a cytokine, interleukin-12 (IL12), which induces $T$ helper function towards a strong cell-mediated response. It also has an inhibitory effect towards humoral immune responses. Replacement of IL-12 in vitro restores antigen recall functions in peripheral blood lymphocytes of HIV-seropositive patients, but it does not enhance recall responses in HIV-seronegative individuals. IL-12 deficiency may play an initial role in immunopathogenesis of HIV infection (31).

The role of lymphoid organs in the pathogenesis of HIV infection has recently been investigated $(32,33)$. Following primary infection, HIV tends to localize more in the lymphoid organs than in the peripheral lymphocytes. The number of cells harboring HIV DNA and RNA is five to 10 times higher in lymph nodes than in peripheral blood lymphocytes (32), and during periods of clinical latency, most of the HIV load is carried in lymphoid organs (34). Follicular dendritic cells may be a major site for HIV replication and a source of circulating CD4 cell infection (33). In contrast to monocytes, which circulate in the blood compartment for one day, lymphocytes migrate every 30 mins, on average, from the blood to lymphoid and nonlymphoid organs and back to the blood via the lymphatics (35). Hence, lymphocyte traffic and the close proximity of infected follicular dendritic cells with CD4 cells suggests that the opportunity for CD4 cells to become infected with HIV is greater 
in lymphoid organs than in the blood compartment.

As a higher proportion of CD4 cells in lymph nodes is activated (25 to $50 \%$, compared with 5 to $10 \%$ in the circulation) (34), they are more susceptible to HIV infection. This may also explain the higher relative viral load that may be present in this compartment. This may be aided by a functional absence of cytotoxic T cell activity in lymph nodes, as previously demonstrated in simian immunodeficiency virus-infected macacques (36). Thus, a comprehensive model of virological and immunological aspects of AIDS pathogenesis will have to consider events at the level of the lymph node.

\section{A UNIFYING HYPOTHESIS}

Although our work is far from complete, our preliminary results can be placed within a general hypothesis of HIV disease progression. An infected individual begins with a given viral load and is placed on antiviral therapy. Over time, the viral strains remain susceptible to the agent being used, or may develop resistance. If susceptibility is maintained in the context of a relatively low viral burden, immune disease will probably be stable. If, however, viral load should increase, the patient may develop more severe immune disease. A number of factors may serve to increase viral load. These include a change in viral phenotype towards more rapidly replicating si strains. Once resistance develops, it may be that clinical disease will remain stable in the setting of a low circulating viral load. Our challenge in this context is to intervene to maintain susceptibility, low viral load and therapeutic efficacy. It is quite clear that no single viral or immune parameter will allow us

\section{REFERENCES}

1. Feinberg MB. The molecular biology and pathogenesis of HIV-1 infection. Curr Opin Infect Dis 1992;5:214-20.

2. Levy JA. Pathogenesis of human immunodeficiency virus infection. Microbiol Rev 1993;57:183-289.

3. Mackewicz C, Levy JA. CD8 cell anti-HIV activity non-lytic suppression of virus replication. AIDS Res Hum Retroviruses 1992:8:1039-50.

4. Tersmette M, deGoede REY, Bert JM, et al. Differential syncytium-inducing capacity of human immunodeficiency virus isolates: frequent detection of syncytium-inducing isolates in patients with acquired immunodeficiency syndrome (AIDS) and AIDS-related complex. J Virol 1988;62:2026-32.

5. Ho DD, Mougdil T. Alam M. Quantitation of human immunodeficiency virus type 1 in the blood of infected persons. N Engl J Med 1989:321:1621-5.

6. Connor RI, Mohri H, Cao Y. Ho DD. Increased viral burden and cytopathicity correlate temporally with CD4 T lymphocyte decline and clinical progression in human immunodeficiency type 1-infected individuals. J Virol 1993:67:1772-7.

7. Conway B, Bechtel LJ, Adler KA, D'Aquila RT, Kaplan JC, Hirsch MS. Comparison of spot-blot and microtitre plate methods for the detection of HIV-1 PCR products. Mol Cell Probes 1992;6:245-9.

8. Conway B, Ko DS, Cameron DW. Quantitative PCR for the measurement of circulating proviral load in to generate data with optimal clinical significance. A composite virological parameter will have to be generated, including measures of cellular proviral load, viral phenotype and antiviral susceptibility and $\mathrm{T}$ helper cell function. As new RNA PCR assays (37) for the measurement of circulating viral load are standardized and made available in retrovirology laboratories, they should be included in this model. We feel that a proper statistical analysis of these measurements will allow us to determine a 'threshold' beyond which disease progression will occur if we do not intervene.

\section{CONCLUSION}

Recent work suggests that many nonvirological factors may contribute to disease progression (38). These include the occurrence of opportunistic infections in and of themselves (39). Certain pathogens have been shown to up-regulate viral replication directly. A weakening of the hosts' specific and nonspecific immune response, by mechanisms that have not been completely elucidated, may also lead to an increased circulating viral burden. Prophylaxis and prompt treatment of opportunistic infections (and immunotherapy, when feasible modalities become available) provide us with key intervention points to control disease progression. Over the coming years, we expect a number of immune modulators and novel antiretroviral agents to become available. With prospective monitoring of composite virological markers and $\mathrm{T}$ helper cell function, we will be in a position to intervene to 'improve' the marker profile, potentially to maintain clinical latency for an indefinite period of time.

HIV-infected individuals. Clin Diagn Virol. (In press)

9. Horwitz JP. Chua J, Noel M. Nucleosides. The monomesylates of 1 - (2'-deoxy- $\beta$-D-lynofuranosyl) thymine. J Organ Chem 1964:29:2076-8.

10. Furman PA, Fyfe JA, St-Clair MH, et al. Phosphorylation of $3^{\prime}$-azido-3'-deoxythymidine and selective interaction of the $5^{\prime}$-triphosphate with human immunodeficiency virus reverse transcriptase. Proc Natl Acad Sci USA 1986;83:8333-7.

11. Larder BA, Darby G, Riehman DD. HIV with reduced sensitivity to zidovudine (AZT) isolated during prolonged therapy. Science 1989;243:1731-4.

12. Richman DD, Grimes JM, Lagakos SW. Effect of stage of disease and drug dose on zidovudine susceptibilities of isolates of human immunodeficiency virus. J Acquir Immune Defic Syndr 1990;3:743-6.

13. Kuritzkes DR, Wellas S, Johnson VA, et al. Baseline prevalence and clinical significance of zidovudine resistance mutations in HIV-1 isolates from patients participating in ACTG protocol 116B/117. First National Conference on Human Retroviruses and Related Infections, 1993. (Abst)

14. Montaner JSG, Singer J, Schecter MT, et al. Clinical correlates of in vitro HIV-1 resistance to zidovudine. Results of the Multicentre Canadian AZT Trials. AIDS 1992:7: 189-96.

15. Conway B. Ko D, Foss N. Filion LG, Cameron DW. PCR-based antiviral susceptibility testing. Can J Infect 
Dis 1992;3(Suppl A):22A-3A.

16. Boucher CAB, Lange JMA, Miedema FF, et al. HIV-1 biological phenotype and the development of zidovudine resistance in relation to disease progression in asymptomatic individuals during treatment. AIDS 1992;6: 1259-64.

17. Kozal M, Shafer R, Winters M, et al. SI phenotype and codon 215 pol gene mutation in PBMC are initially independently associated with CD4 cell decline and increased proviral burden in zidovudine recipients. Programme of the Second International Workshop on HIV Drug Resistance, 1993:52.

18. Conway B, Ko DS, Shaw M. Diaz-Mitoma F. Wells GA. Dynamic relationship of virologic correlates of HIV disease progression. J Cell Biochem 1994;18B:129.

19. Daar ES, Moudgil T, Meyer KD, Ho DD. Transient high levels of viremia in patients with primary human immunodeficiency virus type 1 infection. N Engl J Med 1991;324:961-4.

20. Rosenberg ZF, Fauci AS. Immunopathogenesis of HIV infection. FASEB J 1991;5:2382-90.

21. Allain JP, Laurian Y, Paul DA, et al. Long-term evaluation of HIV antigen and antibodies to p24 and gp41 in patients with hemophilia. N Engl J Med 1993:317:1114-21.

22. Robert-Guroff M, Giardina PJ, Robey WG, et al. HTLV-III neutralizing antibody development in transfusiondependent seropositive patients with B-thalassemia. J Immunol 1987; 138:3731-6.

23. Plata F, Autran B. Pedroza Martins L, et al. AIDS virus-specific cytotoxic T lymphocytes in lung disorders. Nature 1987;328:348-51

24. Walker CM, Moody DJ, Stiles DP, Levy JA. CD8 lymphocytes can control HIV infection in vitro by suppressing virus replication. Science 1986;234:1563-6.

25. Hirsch MS, Curran J. Human immunodeficiency viruses. In: Fields BN, Knipe DM, eds. Fields Virology. New York: Raven Press, 1990:1545-70.

26. Miedema F, Petit AJC, Terpstra FG, et al. Immunologic abnormalities in human immunodeficiency virus (HIV)-infected asymptomatic homosexual men. J Clin Invest 1988;82:1908-14.

27. Lucey DR, Melcher GP. Hendrix CW, et al. Human immunodeficiency virus infection in the US Air Force: seroconversions, clinical staging and assessment of a
T helper cell functional assay to predict change in CD4 T cell counts. J Infect Dis 1991;164:631-7.

28. Clerici M, Shearer GM. A TH1-TH2 switch is a critical step in the etiology of HIV infection. Immunol Today 1993;14:107-11.

29. Van Doesel CJM, Gruters RA, Terpstra FG, Schellekens PTA, Van Lier RAW, Miedema F. Functional and phenotypic evidence for a selective loss of memory T cells in asymptomatic human immunodeficiency virus-infected men. J Clin Invest 1990:86:293-9.

30. Clerici M, Roilides E, Butler KM, et al. Changes in T-helper cell function in human immunodeficiency virus-infected children during didanosine therapy as a measure of antiretroviral activity. Blood 1992;80:2196-202.

31. Clerici M, Lucey DR, Berzofsky JA, et al. Restoration of HIV-specific cell-mediated immune responses by interleukin-12 in vitro. Science 1993;262:1721-4.

32. Pantaleo G, Graziosi C, Butini L, et al. Lymphoid organs function as major reservoirs for human immunodeficiency virus. Proc Natl Acad Sci USA 1991:88:9838-42

33. Spiegel H, Herbst N, Niedobitek G, Foss HD, Stein H. Follicular dendritic cells are a major reservoir for human immunodeficiency virus type 1 in lymphoid tissues facilitating infection of CD4 T-helper cells. Am J Pathol 1992; 140:15-22.

34. Pantaleo G, Graziosi C, Fauci AS. The immunopathogenesis of human immunodeficiency virus infection. N Engl J Med 1993:328:327-35.

35. Westermann J, Pabst R. Lymphocyte subsets in the blood: a diagnostic window on the lymphoid system? Immunol Today 1990;11:406-10.

36. Joag SV, Narayan O. Immunodeficiency-inducing retroviruses. Curr Opin Immunol 1993;5:595-9.

37. Piatak M, Saag MS, Yang LC, et al. High levels of HIV-1 in plasma during all stages of infection determined by competitive PCR. Science 1993;259:1749-54.

38. Fauci AS. Multifactorial nature of human immunodeficiency virus disease: implications for therapy. Science 1993;262:1011-8.

39. Conway B. Mechanisms of HIV-1 activation: co-factors in viral replication and significance of opportunistic infections. Master Lectures in Opportunistic Infections. Milan: Sudler \& Hennessey, 1993. 


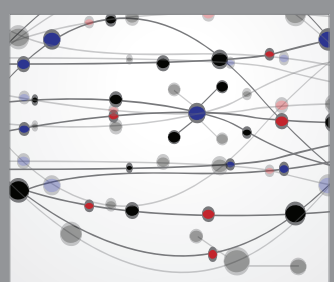

The Scientific World Journal
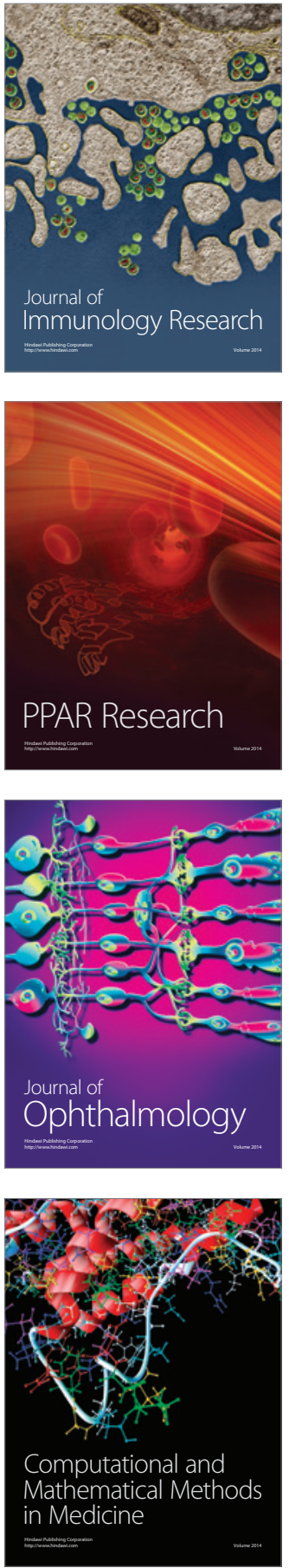

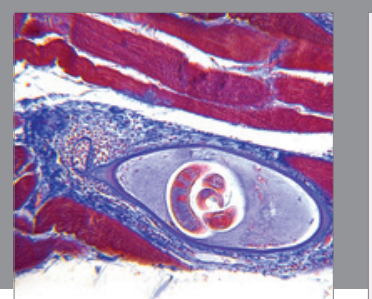

Gastroenterology Research and Practice

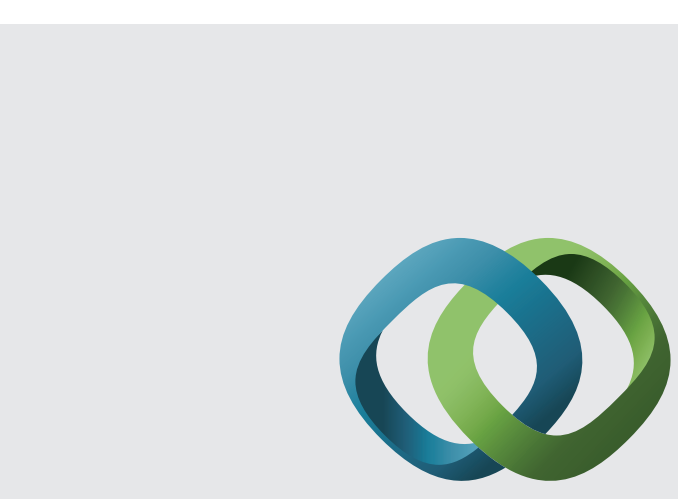

\section{Hindawi}

Submit your manuscripts at

http://www.hindawi.com
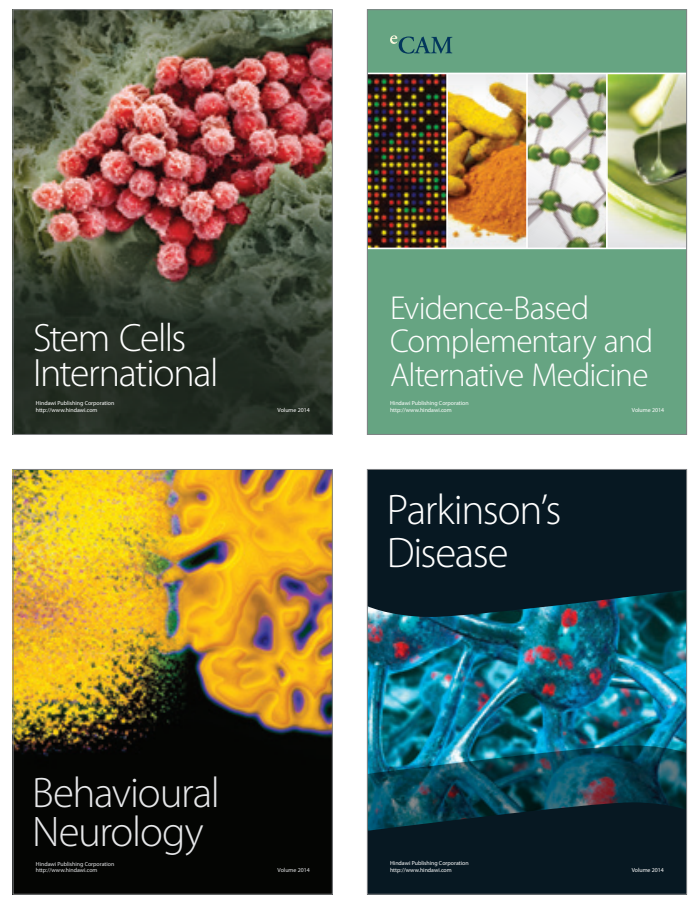
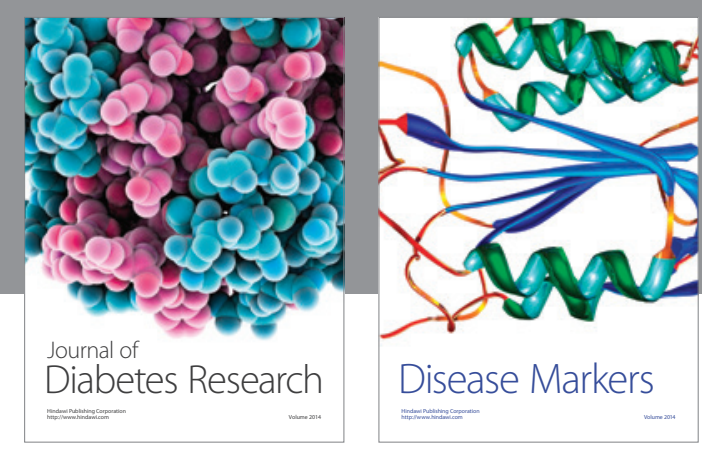

Disease Markers
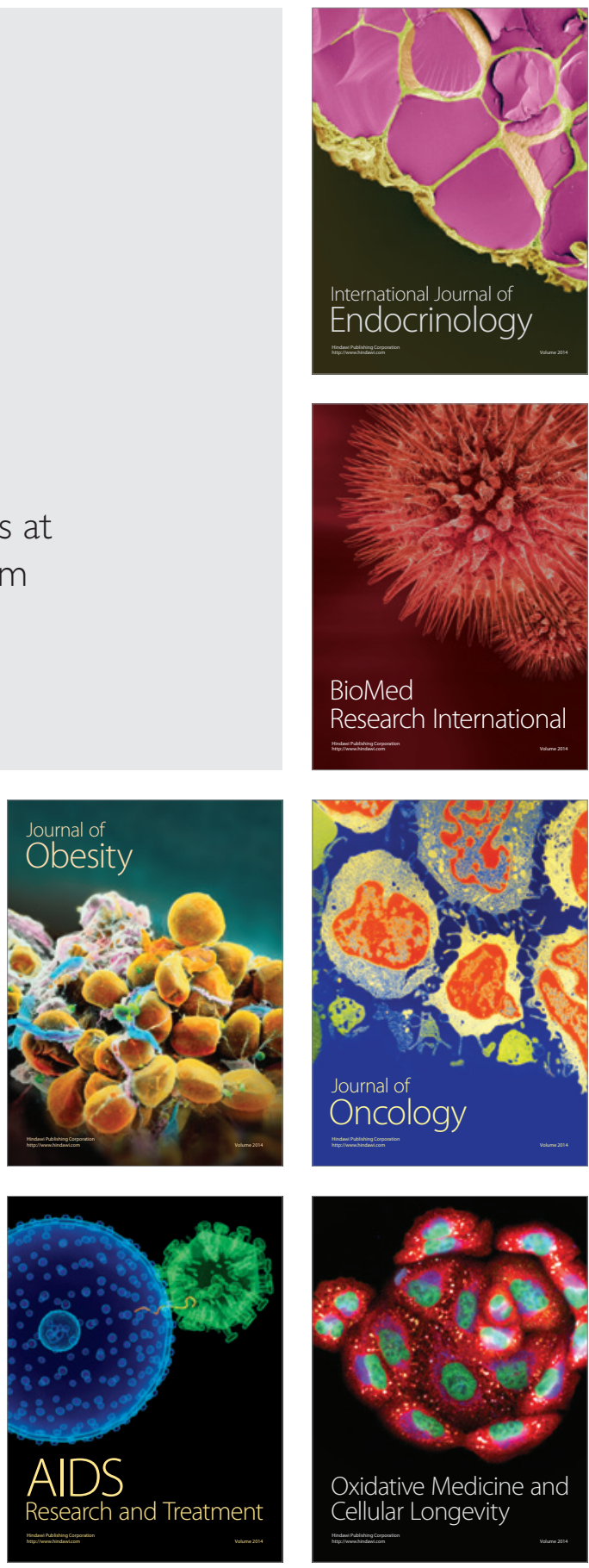